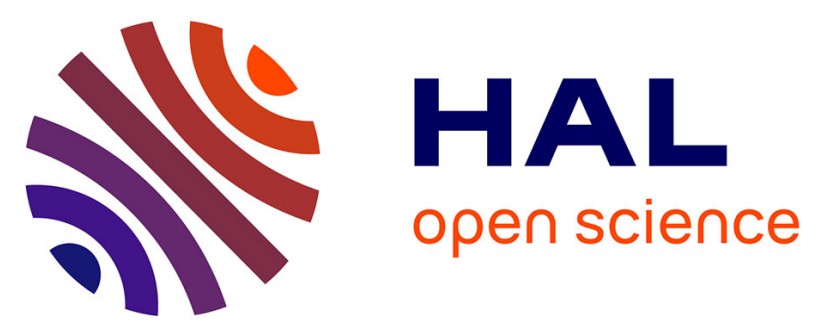

\title{
High prevalence of anti-beta-2 glycoprotein-I and anti-prothrombin antibodies in adult-onset Still's disease. Comment on "Portal vein thrombosis in adult-onset Still's disease: a case report and literature review"
}

Marcin Milchert, Katarzyna Fisher, Jacek Fliciński, Lidia Ostanek, Marek Brzosko

\section{- To cite this version:}

Marcin Milchert, Katarzyna Fisher, Jacek Fliciński, Lidia Ostanek, Marek Brzosko. High prevalence of anti-beta-2 glycoprotein-I and anti-prothrombin antibodies in adult-onset Still's disease. Comment on "Portal vein thrombosis in adult-onset Still's disease: a case report and literature review". Rheumatology International, 2009, 30 (11), pp.1545-1546. 10.1007/s00296-009-1219-6 . hal-00562264

\author{
HAL Id: hal-00562264 \\ https://hal.science/hal-00562264
}

Submitted on 3 Feb 2011

HAL is a multi-disciplinary open access archive for the deposit and dissemination of scientific research documents, whether they are published or not. The documents may come from teaching and research institutions in France or abroad, or from public or private research centers.
L'archive ouverte pluridisciplinaire HAL, est destinée au dépôt et à la diffusion de documents scientifiques de niveau recherche, publiés ou non, émanant des établissements d'enseignement et de recherche français ou étrangers, des laboratoires publics ou privés. 


\section{LETTER TO THE EDITOR}

High prevalence of anti-beta-2-glycoprotein-I and anti-prothrombin antibodies in adult onset Still's disease. Comment on: "Portal vein thrombosis in adult onset Still's disease: a case report and literature review".

Marcin Milchert (凷, Katarzyna Fisher, Jacek Fliciński, Lidia Ostanek, Marek Brzosko

No financial or any other conflicts of interests regarding this paper were recognized. We confirm that the paper has not been published elsewhere.

Department of Rheumatology and Internal Medicine, Pomeranian Medical University, Ul. Unii Lubelskiej 1, 71 - 252 Szczecin, Poland; e-mail: marcmilc@ hotmail.com, Tel. +48914253341; Fax +48914253344 


\section{Dear Sir,}

We have followed with great interest case report by Morita et al. ${ }^{1}$. In our group of 8 patients diagnosed with Adult-onset Still's disease (AOSD) according to Yamaguchi criteria we reviewed presence of antifospholipid antibodies. They were detected in 6 of 8 patients: the most common were anti-prothrombine (anti-PT) followed by anti-beta2 glycoprotein I antibodies (anti- $\beta 2$ GPI) (Table 1). D-dimer level was elevated in all patients, however, no related thrombosis was diagnosed. Only one patient presented with deep vein thrombosis at the time of AOSD relapse, and one woman had a history of miscarriage, however not fulfilling current antifospholipid synd rome classification criteria.

Our first reflection was how difficult differential diagnosis of liver disease in AOSD is, as raised serum aminotransferase (AT) level may be associated with high disease activity and preceded by a raise of acute phase reactants (Fig. 1). In a case described by Morita et al. ${ }^{1}$, portal vein thrombosis occured in a patient with raised AT level and low general disease activity. Our patient with deep vein thrombosis at the time of AOSD relapse (Table 1, no 6) had also concurrent raise of serum AT level, and high concentration of anti- $\beta 2$ GPI and antiPT. Raised concentration of antifospholipid antibodies might help to establish early diagnosis of thrombosis in patients with AOSD.

Coagulation abnormalities are frequently reported in AOSD: there have been reports of various clinical manifestations of thrombotic microangiopathic haemolitic anaemia $(\text { TMHA })^{2}$, disseminated intravascular coagulation (DIC) $)^{3}$, and occasionally, antiphospholip id syndrome ${ }^{4}$. However, the knowledge on etiopathogenesis of hypercoagulative state in AOSD is limited. The presence of anticardiolipin antibodies (aCL) may contribute to the developement of $\mathrm{TMHA}^{5}$.

Only one of our patients was positive for aCL, in contrast with high prevalence of anti$\beta 2$ GPI and anti-PT. These antibodies have not been routinely assessed in previous studies ${ }^{1,2,3}$. The presence of LAC in our patients is not easy to interpret also because Russel's Viper venom test revealed moderate probability of LAC. This might be also explained by deficiency of coagulation factors or presence of their unknown inhibitors, especially because activated partial thromboplastin time (APTT) was short or normal.

Prevalence of anti- $\beta 2$ GPI and anti-PT in AOSD should be further studied to reveal their role in coagulopathies. 
References

1. Morita H, Nishiwaki H, Nagayama Y, Yoshimura A (2009) Portal vein thrombosis in adultonset Still's disease: a case report and literature review. Rheumatol Int Mar 21

2. Sayarlioglu M, Sayarlioglu H, Ozkaya M, Balakan O, Ucar MA (2008) Thrombotic thrombocytopenic purpura-hemolytic uremic syndrome and adult onset Still's disease: case report and review of the literature. Mod Rheumatol 18:403-6

3. Shinohara T, Hidaka T, Matsuki Y, Suzuki K, Ohsuzu F (1999) Calcinosis cutis and intestinal pseudoobstruction in a patient with adult onset Still's disease associated with recurrent relapses of disordered coagulopathy. Intern Med 38:516-20

4. Jinnouchi J, Ooboshi H, Nakamura Y, Kurushima H, Ibayashi S, Fujishima M. (2002) A case of brain ischemia presenting spectacular shrinking deficit in adult-onset Still's disease associated with antiphospholipid antibody syndrome. Rinsho Shinkeigaku 42:629-31

5. Espinosa G, Bucciarelli S, Cervera R, Lozano M, Reverter JC, de la Red G, Gil V, Ingelmo M, Font J, Asherson RA (2004) Thrombotic microangiopathic haemolytic anaemia and antiphospholipid antibodies. Ann Rheum Dis 63:730-36

Table 1 Characteristics of patients with AOSD: fibrinogen (normal 150-400), D - dimer (normal <500), alanine-aminotransferase (ALT, normal <30), ferritin (normal 30-400), antiB2GPI (normal $<20$ ), aCL IgM (normal $<12$ ), anti-PT (normal $<30$ ). All tests were performed in patients with "active" disease, with exception of control antibodies levels (written after slash) assessed at minimum 6 weeks interval. Lupus anticoagulant was detected using dRVVT. All other antibodies were detected by enzyme-linked immunosorbent assay (ELIS A).

\begin{tabular}{ccccccccccc}
\hline No. & sex & age & $\begin{array}{c}\text { fibrino- } \\
\text { gen } \\
(\mathrm{mg} / \mathrm{dl})\end{array}$ & $\begin{array}{c}\text { D- } \\
\text {-dimer } \\
(\mathrm{ng} / \mathrm{ml})\end{array}$ & $\begin{array}{c}\text { ALT } \\
(\mathrm{U} / \mathrm{l})\end{array}$ & $\begin{array}{c}\text { ferritin } \\
(\mathrm{ng} / \mathrm{ml})\end{array}$ & $\begin{array}{c}\text { LAC } \\
\text { anti- } \\
-\beta 2 \mathrm{GPI} \\
(\mathrm{RU} / \mathrm{ml})\end{array}$ & $\begin{array}{c}\text { aCL } \\
\text { IgM } \\
(\mathrm{U} / \mathrm{ml})\end{array}$ & $\begin{array}{c}\text { anti- } \\
\text {-PT } \\
(\mathrm{IU} / \mathrm{ml})\end{array}$ \\
\hline 1. & $\mathrm{f}$ & 17 & 462 & 1000 & 15 & $\mathrm{ND}$ & $\mathrm{ND}$ & 4,2 & 0 & $63 / \mathrm{ND}$ \\
2. & $\mathrm{~m}$ & 18 & $\mathrm{ND}$ & $\mathrm{ND}$ & 18 & $\mathrm{ND}$ & $\mathrm{ND}$ & $<2$ & 0 & $67 / \mathrm{ND}$ \\
3. & $\mathrm{~m}$ & 39 & 591 & 2526 & 204 & 2973 & $\mathrm{ND}$ & $<2$ & 0 & $\mathrm{ND}$ \\
4. & $\mathrm{~m}$ & 17 & 452 & 864 & 186 & 744 & $\mathrm{ND}$ & $<2$ & 0 & 17,2 \\
5. & $\mathrm{~m}$ & 43 & 926 & 1170 & 29 & $\mathrm{ND}$ & $\mathrm{ND}$ & $51 />200$ & $21 / 77$ & $28 / 37$ \\
6. & $\mathrm{f}$ & 26 & 298 & 6415 & 152 & 2120 & $\mathrm{ND}$ & $47 / 10$ & 0 & $>100 / 21$ \\
7. & $\mathrm{f}$ & 22 & 438 & 1595 & 150 & 2156 & $\mathrm{P} / \mathrm{ND}$ & $130 / 118$ & 0 & $\mathrm{ND} / 40$ \\
8. & $\mathrm{~m}$ & 24 & 550 & 1590 & 77 & 421 & $\mathrm{P} / \mathrm{A}$ & 11 & 0 & $30 / \mathrm{ND}$ \\
\hline
\end{tabular}

ND- not done, P- present, A- absent. 


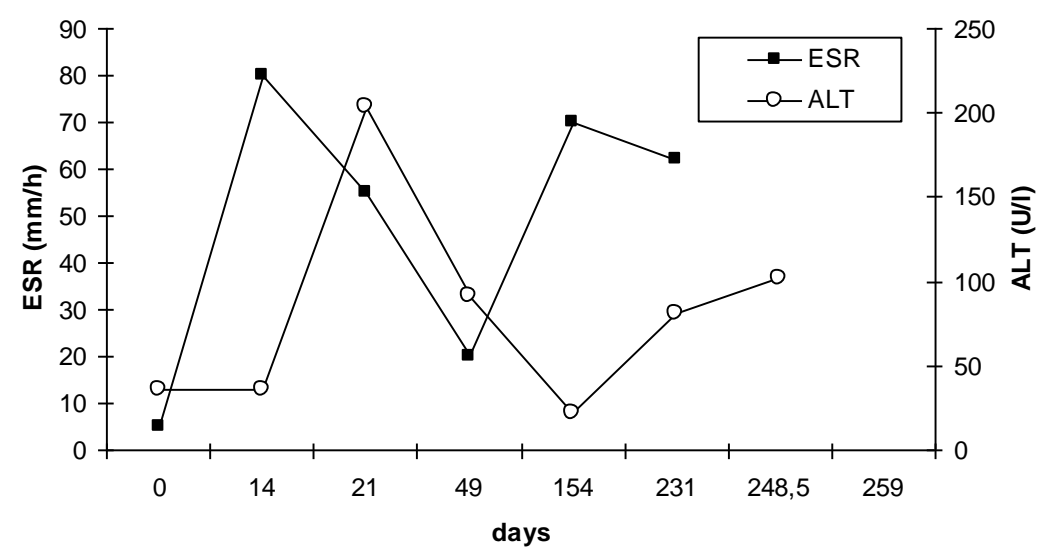

Fig. 1 Change of ESR and alanine-aminotransferase (ALT) values in one of the patients. 